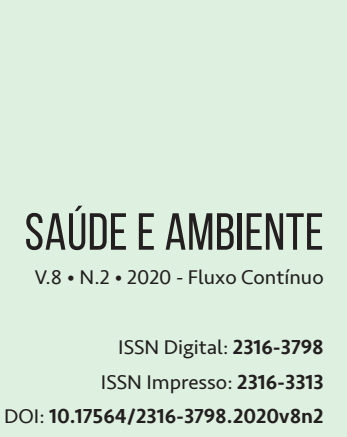

\section{A REVIEW ON THE USE OF REMDESIVIR IN THE CURRENT VIROSIS COVID-19}

UMA REVISÃO SOBRE O USO DE REMDESIVIR NA ATUAL VIROSE COVID-19

UNA REVISIÓN SOBRE EL USO DE REMDESIVIR ENLA VIROSIS ACTUAL COVID-19
Ana Maria Marinho Andrade de Moura ${ }^{1}$ Anaís Concepción Marinho Andrade de Moura² Dany Geraldo Kramer ${ }^{3}$

\section{ABSTRACT}

Remdesivir (GS-5734) is a drug designed for application in patients with Ebola, being used in patients in the coronavirus outbreak in the Middle East. After internalization of the drug, at the cellular level, it is converted into its active form GS-441524, and binds viral RNA polymerase (RdRp) blocking viral replication. Thus, the present study aimed to discuss the potential use of Remdesivir in coronovavirus infections. Some observed studies report promising results in the recovery of critically ill patients with COVID 19, however, there are reports of serious adverse reactions, which led to the discontinuation of therapy with this drug. Thus, measuring the efficacy and safety of Remdesivir in the treatment of COVID 19 will require broader randomized, controlled and double-blind clinical trials, so that the data and scientific information generated can guide treatment protocols for this drug.

\section{KEYWORDS}

Remdesivir; Coronavirus; Therapy. 


\section{RESUMO}

O Remdesivir (GS-5734) é um medicamento projetado para aplicação em pacientes com Ebola, sendo utilizado em pacientes no surto de coronavírus do Oriente Médio. Após a internalização da droga, em nível celular, ela é convertida em suaa forma ativa GS-441524, e se liga RNA polymerase viral (RdRp) bloqueando a replicação viral. Assim, o presente estudo teve como objetivo discorrer sobre o uso potencial do Remdesivir em infecções por coronovavírus. Alguns estudos observados, relatam resultados promissores na recuperação de pacientes graves com COVID 19, no entanto, há relatos de reações adversas graves, que levaram a suspensão da terapêutica com esta droga. Assim, a medição da eficácia e segurança do Remdesivir na terapêutica do COVID 19 exigirá ensaios clínicos randomizados, controlados e duplo-cegos mais amplos, de forma que os dados e informações cientificas geradas, possam direcionar protocolos de tratamento desta droga.

\section{PALAVRAS-CHAVE}

Remdesivir; Coronavírus; Terapia.

\section{RESUMEN}

Remdesivir (GS-5734) es un medicamento diseñado para su aplicación en pacientes con Ébola, que se utiliza en pacientes con brote de coronavirus en el Medio Oriente. Después de la internalización del fármaco, a nivel celular, se convierte en su forma activa GS-441524, y se une a la ARN polimerasa viral (RdRp) bloqueando la replicación viral. Por lo tanto, el presente estudio tuvo como objetivo discutir el uso potencial de Remdesivir en infecciones por coronovavirus. Algunos estudios observados reportan resultados prometedores en la recuperación de pacientes críticos con COVID 19, sin embargo, hay informes de reacciones adversas graves, que llevaron a la interrupción de la terapia con este medicamento. Por lo tanto, medir la eficacia y seguridad de Remdesivir en el tratamiento de COVID 19 requerirá ensayos clínicos aleatorios, controlados y doble ciego más amplios, de modo que los datos y la información científica generados puedan guiar los protocolos de tratamiento para este medicamento.

\section{PALABRAS CLAVE}

Remdesivir; Coronavirus; Terapia. 


\section{INTRODUCTION}

SARS-COV-2 is a virus that occurs in birds and mammals, belonging to the Coronoviridae family, which appeared in China at the end of 2019, having a high rate of infectivity, presenting absolute monthly numbers of deaths higher than other previous viruses as it was In the case of EBOLA, Chicungunha, Dengue and Zica (GIWA et al., 2020; KRAMER et al., 2020; MUNSTER et al., 2020).

This virus has an RNA genome and envelope, and may be rounded or pleomorphic. Adhered to the viral envelope, are the glycoproteins, which are responsible for fixing the virus to the host cell (GIWA et al., 2020). They also present the hemagglutinin-stearase (HE) protein that assist in viral adhesion (MALIK et al., 2020; KORDA et al., 2020; EASTMAN et al., 2020).

The coronavirus can infect some people, and they can remain asymptomatic, in other cases they develop symptoms of colds (cough, fever, headache and myalgia). The patient's clinical condition may worsen, especially if he has comorbidities (Diabetes and cardiovascular diseases), progressing to life-threatening respiratory, renal, liver and heart complications (KORDA et al., 2020; EASTMAN et al., 2020).

However, there is currently no specific treatment for COVID 19, and several drugs are being tested, including Remdesivir, which is a single stereoisomer monophosphoramidate prodrug of a nucleoside analog, which acts on synthesized RNA chains, thus blocking viral replication (CAO et al., 2020; EASTMAN et al., 2020). Animal experiments have indicated that Remdesivir can effectively reduce the viral load in the lung tissue of mice infected with MERSS-VOC, increase and alleviate pathological damage to the lung tissue (CAO et al., 2020). In this context, the present study aimed to discuss the potential use of Remdesivir in the treatment of COVID 19.

\section{CORONAVÍRUS}

Coronaviruses are classified into four genera, Alphacoronavirus, Betacoronavirus, Gammacoronavirus, and Deltacoronavirus. COVID 19 belongs to Betacoronavirus, being characterized as enveloped and RNA virus (CHAN et al., 2019).

Coronaviruses are associated with etiologic agents of respiratory and intestinal infections in animals and humans. In these, they usually result in asymptomatic conditions or the development of symptoms similar to the common cold. In patients who fall into the risk group (the elderly and those with comorbidities), they can eventually lead to serious infections, which require hospitalization in Intensive Care Units - ICU (CAO et al., 2020; CHAN et al., 2020).

Compared to SARS and MERS, SARS-CoV-2 has high transmissibility and infectivity. The continuous transmission of SARS-Cov-2 in Wuhan suggests that tertiary and quaternary spread has occurred. Compared to primary and secondary dissemination, during which SARS-Cov-2 was transmitted from animal to human and between humans, the rate of transmission has increased and pathogenicity has yet to be assessed (WRAPP et al., 2020; YUEN et al., 2020). 
The replication of the coronavirus, illustrated in Figure 1, begins with the adhesion of the viral Glycoprotein S to the cell receptor, followed by the internalization of the virus. Thus, viral RNA is released and used for synthesis of viral RNA-dependent RNA polymerase (RdRp). RdRp will be used for RNA synthesis that will lead to the synthesis of the components of the viral structure. Following this, the virus will be assembled and undergo exocytosis, which may infect new cells (YUEN et al., 2020; WANG, L.S. et al., 2020; HUANG et al., 2020).

Figure 1 - Replication of the coronavirus

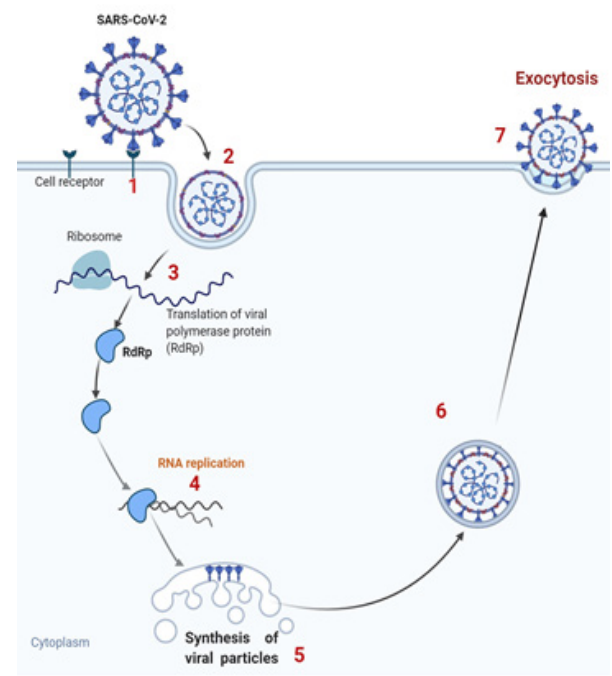

Source: Created with www.biorender.com

Symptoms may appear between two to fourteen days after the initial contact, being frequent in coronaviruses: dry cough, fever, sore throat, difficulty breathing, chest pain, diarrhea, pneumonia, and may have heart and kidney problems worsening to death (WANG, L.S. et al., 2020; HAFIZ et al., 2020).

Patients with more severe clinical conditions require hospitalization, often in Intensive Care Units, however, there is still no proven specific drug therapy. Wang, L.S. and collaborators (2020) report that several therapeutic variations are observed in an attempt to find an effective medication, indicating: 1- Antiviral Medical Treatment in the West, which basically uses allopathic medicines; 2- Chinese Medical Treatment - prescribes a decoction of part of the lung and detoxification, associated with other peculiar Chinese substances; 3 - Immuno-Reinforcement Therapy - which seeks to increase the body's immunity through the use of interferon; 4- Convalescent Plasma Therapy - considered more effective than high doses of hormones in patients with severe SARS; 5 - Auxiliary Blood Purification Treatment.

In drug therapy, tests with oseltamivir, peramivir, zanamivir, ganciclovir, acyclovir and ribavirin were observed, with no effective responses to date for COVID 19 therapy (CAO et al., 2020; PAGLIARULO, 2020). Cao and collaborators (2020) point out that Remdesivir, demonstrated efficacy in tests related to infection by the MERS-CoV virus and Ebola, and thus can represent a potential drug for the 
treatment of patients in this pandemic. Pagliarulo (2020) cites experiments on human cell cultures and guinea pigs that indicated that Remdesivir could have activity against the coronavirus like MERS.

\section{REMDESIVIR}

Remdesivir, or GS-5734, is an analogue of adenosine triphosphate first described in the literature in 2016 as a potential treatment for Ebola. This drug was also used to treat patients during the MERS outbreak. The recommended dosage for the treatment of MERS involved an initial dose of $200 \mathrm{mg}$, followed by maintenance doses of $100 \mathrm{mg}$ once daily, with dosage ranging from 5 to 10 days of administration (AGOSTINI et al., 2018; DRUG BANK, 2020 ; MORSE et al., 2020).

Remdesivir (GS-5734) is a prodrug, which will be converted into its active form (GS-441524) inside the infected cell (1). In sequence, the GS-441524 molecule binds to the viral RNA polymerase (RdRp) blocking (2), thereby blocking the transcription of the viral RNA (3), thereby inhibiting the replication of COVID 19 (Figure 2) (CAO et al., 2020; AGOSTINI et al., 2018; YIN et al., 2020; JIANG et al., 2020; HILLAKER et al., 2020; SHEAHAM et al., 2020).

Yin and collaborators (2020) corroborate this mechanism of action, stating that RNA polymerases (RdRp) are the main target of existing nucleotide drugs, such as Remdesivir, as they are recognized as substrates analogous to these RdRp, blocking the viral transcription sequence.

Figure 2 - Remdesivir's mechanism of action

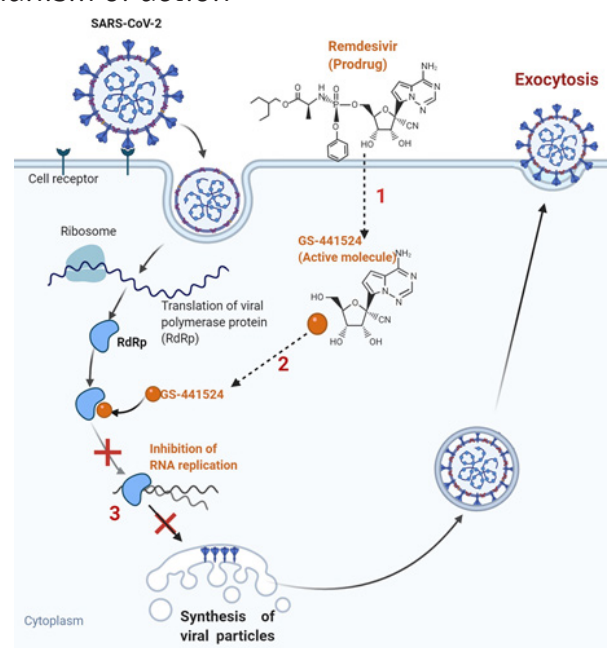

Source: Created with www.biorender.com

The application of Remdesivir was reported by Jiang and collaborators (2020), who analyzed the clinical characteristics of 738 Chinese patients, who presented symptoms of fever ( $90 \%$ or more), 
cough (75\%) and dyspnoea (> 50\%), being The authors indicated the importance of using Remdesivir, as they reported improvements in the clinical setting of patients, even with the late start of treatment for the coronavirus. Similar observation made by Hillaker and collaborators (2020), who pointed out that Remdesivir could be the best drug potential for COVID-19.

Sheaham and collaborators (2020) tested Remdesivir in mice infected with Middle Eastern Respiratory Syndrome (MERS) - COV, with less damage to lung tissues than those tested with Lopinavir / Ritonavir associated with Interferon.

Grein and collaborators (2020) followed 61 treated patients according to the standard protocol with remdesivir (200 mg on day 1 , followed by $100 \mathrm{mg} /$ day on the remaining 9 days). At the beginning of the study, 30 patients (57\%) were on mechanical ventilation and 4 ( $8 \%$ ) on extracorporeal membrane oxygenation. During an average follow-up of 18 days, 36 patients (68\%) had an improvement in the oxygen support class, including 17 of 30 patients (57\%) receiving extubated mechanical ventilation. Despite the use of Remdesivir, there were $13 \%$ of deaths among treated patients.

Wang, Y. and collaborators (2020) followed 237 patients in a randomized, double-blind study (158 treated with Remdesivir and 79 for placebo). The authors indicated that patients who received Remdesivir had a time to clinical improvement numerically faster than those who received placebo.

The use of Remdesivir can lead to adverse reactions that lead to the suspension of treatment, being reported as the most common: Increase in Liver Enzymes; - Diarrhea; - Rash; - Renal impairment and hypotension. Of these, $23 \%$ had serious adverse events, such as: Multiple Dysfunction Syndrome, - - Septic Shock, - Acute Kidney Injury and Hypotension (GREIN et al., 2020; WANG, Y. et al., 2020).

Thus, measuring the efficacy and safety of Remdesivir in the treatment of COVID 19 will require broader randomized, controlled and double blind clinical trials, so that the data and scientific information generated can guide treatment protocols for this drug.

\section{CONCLUSIONS}

It is concluded that the potential use of Remdesivir in the treatment of COVID 19 has positive aspects, since some studies have been shown to be effective in inhibiting viral replication and stabilizing patients.

New randomized, controlled and double-blind clinical trials should be performed so that the safety and efficacy of this drug can be validated, since adverse reactions have justified the discontinuation of therapy, and thus can guide treatment protocols for this drug.

\section{REFERENCES}

AGOSTINI, M. L. et al. Coronavirus susceptibility to the Antiviral Remdesivir (GS-5734) is mediated by the viral polymerase and the proofreading exoribonuclease. Am. Soc. Microbiol., v. 9, n. 2, p. e00221-18, 2018. 
CAO, Y. et al. Remdesivir for severe acute respiratory syndrome coronavirus 2 causing COVID-19: Na evaluation of the evidence. Travel Med. Infect. Dis., v. 35, p. 101647, 2020.

CHAN, J. F. W. et al. Interspecies transmission and emergence of novel viruses: lessons from bats and birds. Trends Microbiol., v. 21, p. 544-555, 2019.

DRUG BANK. Remdesivir - DB14761. 2020.

EASTMAN, R. T. et al. Remdesivir: A review of its discovery and development leading to human clinical trials for treatment of COVID-19. ACS Cent. Sci., v. 6, n. 5, p. 672-683, 2020.

GIWA, A. et al. Novel coronavirus COVID-19: an overview for emergency clinicians. Emerg. Med. Pract., v. 22, suppl 2, p. 1-21, 2020.

GREIN, J. et al. Compassionate use of Remdesivir for patients with severe Covid-19, N. Engl. J. Med., v. 382, n. 24, p. 2327-2336, 2020.

HAFIZ M. N. et al. The emergence of novel-coronavirus and its replication cycle - An overview Iqbal et al. J. Pure Appl. Microbiol., v. 14, n. 1, p. 13-16, 2020.

HILLAKER, E. et al. Delayed initiation of Remdesivir in a CoviD-19 positive patient.

Pharmacotherapy, v. 40, n. 6, p. 592-598, 2020.

HUANG, C. et al. Clinical features of patients infectade with 2019 novel coronavirus in Wuhan, China. Lancet., v. 395, n. 10223, p. 497-506, 2020.

JIANG, F. et al. Review of the clinical characteristics of Coronavirus 2019 (COVID-19). J. Gen. Intern. Med., v. 35, p. 1545-1549, 2020.

KORDA, R. et al. Coronavirus: Symptômes, transmission et Traitement du Covid-19. Le Parisien on ligne, Publié le 25 mars 2020 à 20h24, modifié le 10 avril 2020 à 11h35. Available in: https://www. leparisien.fr/societe/coronavirus-definition-transmission-symptomes-traitement-l-essentiel-sur-lecovid-19-25-03-2020-8287998.php. Access in: 25 apr. 2020.

KRAMER, D. et al. Coronavirus in pregnant Women: Literature Review. Am. Sci. Res. J. Eng. Technol. Scien., v. 67, n. 1, p. 73-79, 2020.

MALIK, Y. S. et al. Emerging novel coronavirus (2019-nCoV) - current scenario, evolutionary perspective based on genome analysis and recent developments. Vet. Q., v. 40, n. 1, p. 68-76, 2020. 
MORSE, J. S. et al. Learning from the past: possible urgent prevention and treatment options for severe acute respiratory infections caused by 2019-nCoV. Chembiochem., v. 21, n. 5, p. 730-738, 2020.

MUNSTER, V. J. et al. A novel coronavirus emerging in China - key questions for impact assesment. N. Engl. J. Med., v. 382, n. 8, p. 692-694, 2020.

PAGLIARULO, N. A closer look at the ebola drug that's become the top hope for a coronavirus treatment. BIOPHARMADIVE, Published March 5, 2020. Available in: https://www.biopharmadive. com/news/coronavirus-remdesivir-gilead-antiviral-drug-covid-19/573261/\#: :text=Hopes\%20 are\%20highest\%20for\%20remdesivir,And\%20that's\%20remdesivir.\%22. Access in: 25 apr. 2020.

SHEAHAM, T.P. et al. Comparative therapeutic of remdesivir and combination lopinavir, ritonavir, a interferon beta against MERS-CoV. Nature Comm., v. 11, p. 222, 2020.

WANG, L. S. et al. A review of the 2019 novel coronavirus (covid-19) based on current evidence. Int. J. Antimicrob. Ag., v. 55, n. 6, p. 105948, 2020.

WANG, Y. et al. Remdesivir in adults with severe COVID-19: a randomised, double blind, placebocontrolled, multicenter trial. Lancet., v. 395, n. 10236, p. 1569-1578, 2020.

WRAPP, D. et al. Cryo-EM structure of the 2019-nCoV spike in the prefusion conformation. Science, v. 367, n. 6483, p. 1260-1263, 2020.

YIN, W. et al. Structual basis for inhibition of the RNA-dependent RNA polymerase from SARS-CoV-2 by Remdesivir. Science, v. 368, n. 6498, p. 1499-1504, 2020.

YUEN, K. S. et al. SARS-CoV-2 and COVID-19: The most important research questions. Cell Biosci., v. 10, p. 40, 2020. 
1 Mestre em Ciências Farmacêuticas; Farmcêutica; Professora Adjunto da Universidade Federal do Rio Grande do Norte UFRN, Campus Túnel. E-mail: annydm_@hotmail.com

2 Professora de Medicina, Universidade Potiguar. E-mail: mouraanais10@gmail.com

3 Doutor em Engenharia Mecânica; Professor do Programa de Pós-Graduação em Saúde do Família do Nordeste RENASF - Universidade Federal do Rio Grande do Norte UFRN, Campus Túnel. E-mail: dgkcs@yahoo.com.br

\section{(2) (1) (2)}

Este artigo é licenciado na modalidade acesso abertosob a Atribuição-Compartilhalgual CC BY-SA

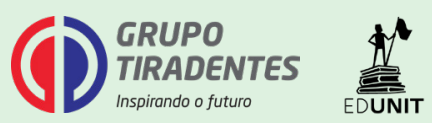

